Faculty of Humanities and Social Sciences,

Faculty of Humanities and Social Sciences, University of Split (Croatia)

\title{
Maja Ljubetić
}

Faculty of Humanities and Social Sciences, University of Split (Croatia)

\section{SOCIAL AND EMOTIONAL COMPETENCIES AND ACADEMIC ACHIEVEMENT IN ELEMENTARY SCHOOL STUDENTS}

Abstract: Various scientific researches undoubtedly confirm the importance of children's social and emotional competencies in their achievement and the overall life satisfaction. Therefore, the conclusion that logically follows is the premise that children who have developed these competencies tend to be more caring, happy, responsible, with an overall better psycho-physical health and success in life in general. This research aimed to examine social and emotional competencies in elementary school children by using the Behavioural and Emotional Rating Scale 2nd edition (Epstein, 2004), and to examine their connection to academic achievement. Participants were sixth-grade students from three elementary schools in Split and one elementary school in Šstanovac $(\mathrm{N}=115)$. The results pointed out to the average and above-average social and emotional strengths of the majority of participants, while there was no significant correlation found between the overall social and emotional competencies (Strength Index) and the school achievement. There was no positive correlation between the development of social and emotional competencies and the academic achievement, in a way that children with more developed competencies had better success in school. A significant positive correlation was found only with School Functioning subscale and the fifth and sixthgrade school achievement.

Key words: Academic achievement, strength index, social and emotional competencies, elementary school students

\footnotetext{
* Toni Maglica, tmaglica@ffst.hr
} 


\section{INTRODUCTION}

Contemporary conceptions of education and its role in the holistic development of an individual are increasingly moving away from the traditional paradigm, more specifically, from the aim of education to develop just the cognitive aspect in students. An attention of scholars and practitioners becomes more focused on the research of the role of social and emotional development in achieving school success, as well as on the success of an individual in the future and all aspects of life (Elias, Zins, Weisberg, Frey, Greenberg, Haynes and associates, 1997). Unfortunately, the traditional school teaches and addresses these factors unsystematically, which enables and valorises them insufficiently. Luckily, the number of scholars asserting the importance of acquiring and strengthening child's social and emotional competencies during schooling is on the rise (Gresham \& Elliott, 2017; Munjas Samarin \& Takšić, 2009).

The term social and emotional competencies differ from social and emotional learning in a way that it denotes the ability to understand, manage, and express social and emotional aspects of life. It enables a person to successfully manage life tasks such as learning, forming relationships, solving everyday problems and adjusting to complex growth and development requirements (Elias et al., 1997). More recent understandings of social and emotional competencies in the European context have been provided by Cefai, Bartolo, Cavioni, \& Downes (2018). Their theoretical frame consists of two broad competence domains: intrapersonal (Self) and interpersonal (Others) competencies. Each of these two domains has two dimensions: Management and Awareness. As a result, there are four categories of competencies: self-awareness, social management, social awareness, and social management. Regarding the selfmanagement competence, the authors suggest two additional dimensions, 
namely, resilience skills and academic learning-oriented skills. Schonert-Reichl, Kitil, \& Hansen-Peterson (2017) have classified social and emotional competences in five domains: self-awareness, self-management, social awareness, relationship skills, and responsible decision-making.

On the other hand, social and emotional learning is considered as a process of development in order to acquire core competencies acknowledging and managing emotions, developing care and interest for others, responsible decision-making, forming positive relationships, and handling challenging situations successfully (Elias, Parker, Kash, Weissberg, \& O’Brien, 2008; Collaborative for Academic, Social, and Emotional Learning [CASEL], 2013). Integration of social and emotional learning into school curriculums has unveiled various benefits useful to all participants of the educational system (Gresham \& Elliott, 2017). It has been posited by educators that successful learning is inevitable by integrating different social and emotional learning programs (Collaborative for Academic, Social, and Emotional Learning [CASEL], 2003). The aforementioned influence an attitude towards school and academic performance both directly and indirectly, and create positive relations with teachers and peers. Children who have learned how to build and maintain quality relationships with peers early on, show prosocial behaviour and are generally accepted by their peers at older age (Miljković, Đuranović, \& Vidić, 2019). Integration of social, emotional, and academic factors results in successful learning and positive developmental outcomes in children and youth.

Elias et al. (1997) emphasize that educators today have an improved perspective over what common sense advice to everyone: when schools systematically and structurally enable acquiring and developing social and emotional competencies in students, academic achievement significantly 
increases, as visible, and behavioural problems incidence decreases. Polly and Britton (2015, according to Miljković, Đuranović, \& Vidić, 2019) state that every student has virtues to a greater or a lesser extent, as well as character strengths. If students learn how to appropriately use their character strengths, they can yield various positive consequences in self-growth and selfdevelopment. Such individuals are happier, more self-confident and selfrespectful, have more energy and vitality, experience less stress, are more psychologically resilient, reach their goals more often, are more successful at work, and they try harder. In general, they are more efficient in their personal growth and development (Linley et al., 2010, according to Miljković, Đuranović, \& Vidić, 2019: 61). All things considered, quite simple and straightforward questions arise: Should educational institution enable the development of character strengths and promote the aforementioned virtues? Should every teacher, educator, and principal have them? If the answers are affirmative, which we do not doubt, it is indisputable that more attention in educating children and students should be given to social and emotional learning in our institutions.

\section{MATERIALS AND METHODS}

Aims and objectives of the research

The research aims to examine social and emotional competencies in students, and determine how they are related to academic achievement. Considering the aim, objectives of the research are the following:

- to determine students' social and emotional competencies by using the Behavioural and Emotional Rating Scale Questionnaire -2nd Edition, BERS-2 (Epstein, 2004), 
- to examine the correlation between social and emotional competencies and the students' academic achievement, and

- to explore the influence of individual social-emotional competencies on the school achievement.

Hypotheses

Given the determined theoretical framework and previous research findings, three hypotheses were appointed:

H1: Most of the participants will attain average results on the scale of social and emotional competencies.

$\mathrm{H} 2$ : There is a positive correlation between the Strength Index and the school achievement, in a way that children attaining a higher score on the Strength Index will have a better school achievement as well.

H3: There is a positive correlation between the development of social and emotional competencies and the school achievement, in a way that children with developed social and emotional competencies have a better school achievement.

\section{Sample}

The sample consisted of 115 participants (68 female and 47 male). Participants were sixth-grade students from four elementary schools (Split and Šestanovac).

\section{The instrument}

The instrument used in this study was the Behavioural and Emotional Rating Scale-2nd Edition, BERS-2 (Epstein, 2004). This Scale focused on 
determining behavioural and emotional strengths in children and youth aged 11 to 18 . The instrument was bought from the author, translated and linguistically adapted to the targeted population. The Scale was created as a result of a paradigm shift in measuring, which focused on children's strengths and recognized that even those children with extremely challenging behaviours had distinguishing strengths, which could be a base for an intervention approach or treatment (Buckley \& Epstein, 2004). The original Scale has three versions (Youth Rating Scale, Parent Rating Scale, and Teacher Rating Scale). Youth Rating Scale was used in this study, and the results were an indicator of the development of their social and emotional competencies. The Scale consisted of 52 items which measured five strengths or subscales: Interpersonal Strength, Family Involvement, Intrapersonal Strength, School Functioning, and Affective Strength. Interpersonal Strength subscale consisted of 15 items and referred to the child's ability to control its emotions and behaviours in social situations (e.g. "I can express my anger in the right way"). Family Involvement measured participation and relationships with his or her family and consisted of 10 items (e.g. "I get along well with my family."). Intrapersonal Strength subscale in a broad sense measured the outlook on the child's own competence and accomplishments, and it consisted of 11 items ("I know when I am happy and when I am sad."). School Functioning included 9 items, and it focused on the competence in school and classroom tasks (e.g. "I complete my homework."). Affective Strength subscale measured the child's ability to accept love and affection from others, but also to express feelings towards others. It contained 7 items (e.g. "I care about how others feel."). The original Scale had one more Subscale, Career Strength, but since it was optional, and given the age of the 
participants, it was not used in this study. The items in the Scale were rated on a 4-point Likert scale from 0 (not at all like) to 3 (very much like).

BERS-2 measures four out of five core competencies listed by CASEL (2003), namely, Self-Awareness, Self-Management, Social Awareness, and Relationship Skills (Haggerty, Elgin, \& Woolley, 2011). Since BERS-2 is a diagnostic assessment tool, results can be interpreted by using two constructs, scaled scores derived from results on the five subscales (the mean of the scaled scores is set at 10 and standard deviation at 3), and the Strength Index of the adolescent. It is considered as the most reliable of all the scores generated in the BERS-2, because it provides an overall rating of the child's behavioural and emotional strengths. It is computed by summing the scaled scores of the subscales, and then converting that sum into the Strength Index. Estimates that a child will receive certain scores on the Scale are shown in Table 1.

Table 1. Guidelines for Interpreting BERS-2 Subscale Standard Scores and Strength Index

\begin{tabular}{ccccc}
\hline $\begin{array}{c}\text { Behavioural and } \\
\text { Emotional }\end{array}$ & $\begin{array}{c}\text { Subscale } \\
\text { Scaled }\end{array}$ & $\begin{array}{c}\text { Probability } \\
\text { Student Has }\end{array}$ & $\begin{array}{c}\text { BERS-2 } \\
\text { Strength Index }\end{array}$ & $\begin{array}{c}\text { \% included in } \\
\text { Bell-Shaped } \\
\text { Distribution }\end{array}$ \\
\hline Sery Superior & $17-20$ & ExD & & 2.34 \\
Superior & $15-16$ & Extremely low & $121-130$ & 6.87 \\
Above Average & $13-14$ & Very low & $111-120$ & 16.12 \\
Average & $8-12$ & Low & $90-110$ & 49.51 \\
Below Average & $6-7$ & High & $80-89$ & 16.12 \\
Poor & $4-5$ & Very High & $70-79$ & 6.87 \\
\hline
\end{tabular}

Note. $E B D=$ emotional and behavioural disorder.

When interpreting individual results, the Strength Index score is the most important one. If it is 90 or higher, the child probably has sufficient behavioural and emotional strengths. Subscale scaled scores from 8 through 
12, or 90 through 110 for the Strength Index, are considered the average scores for children without diagnosed emotional and behavioural disorders. Subscale scaled scores of 6 or 7, or 80-89 for the Strength Index scores, are deemed below borderline scores in terms of strengths, and children receiving these scores may or may not have behavioural disorders. In this case, there is no justified assumption that a child has an emotional and behavioural disorder. However, additional tests, parent interviews, and direct observation of the child should be gathered to aid the diagnosis. Significantly low subscale scaled scores are all scores below 6 or the Strength Index below 80 . If it is lower than 70, then the child is likely to have little personal strengths, and an emotional and behavioural disorder probably is to be diagnosed. Such low scores may be indicators of poor self-concept, immaturity or deviant behaviours, or negative perception and feelings towards peers and adults (Epstein, 2004).

The conducted research globally has proven that the instrument has good metric characteristics (Buckley \& Epstein, 2004; Sointu, Savolainen, Lambert, Lappalainen, \& Epstein, 2014; Hao, 2015; Lambert, Sointu \& Epstein, 2018). Reliability coefficients in our study speak in favour of the reliability of the instrument and its components, with Cronbach alpha values: Strength Index $=0.95$; Interpersonal strength $=0.89$; School Functioning $=$ 0.83; Intrapersonal strength $=0.82$; Affective strength $=0.78$; Family Involvement $=0.79$. School achievement data has been acquired from grade point averages in the first to the fourth grade, the fifth and the sixth grade in numerical values from one to five. 


\section{Procedure}

The research was conducted during October 2018, with permission from the headmaster obtained before the research. Informed permissions from parents about their children's participation were also attained beforehand. The participants were given a thorough explanation of the purpose of the research, and it was emphasized that the participation was anonymous and voluntary. Additionally, they were told that they were free to withdraw from participating at any time. The form took ten minutes to complete.

\section{RESULTS AND DISCUSSION}

Descriptive statistics

Table 2 displays descriptive parameters of the results obtained from the study. Given the Kolmogorov-Smirnov test results, distributions of IS, FI, IaS, and SI variables significantly deviate from the normal distribution, whereas distributions of SF and AS variables do not. The skewness of all variables is in the range from -1 through -2.51 which is considered acceptable. Moreover, kurtosis values of all variables are set in the range from 2.34 to 10.46, which represent a high deviation from the kurtosis of a normal distribution. Considering the K-S test results and the kurtosis values of the results, the distribution of gross results significantly deviates from the normal distribution and, accordingly, non-parametric statistics have been used for data analysis. 
Table 2. Descriptive parameters of variables

\begin{tabular}{ccccccccc}
\hline & $\mathrm{N}$ & $\mathrm{M}$ & $\mathrm{SD}$ & Min & Max & skewness & kurtosis & $\mathrm{K}-\mathrm{S}$ \\
\hline $\begin{array}{c}\text { Interpersonal } \\
\quad 115\end{array}$ & 34.90 & 7.78 & 0 & 45 & -1.93 & 6.07 & $.14^{*}$ \\
$\quad \begin{array}{l}\text { Strength } \\
\text { Family }\end{array}$ & 115 & 24.97 & 4.50 & 6 & 30 & -1.84 & 4.56 & $.17^{* *}$ \\
$\begin{array}{c}\text { Involvement } \\
\text { Intrapersonal }\end{array}$ & 115 & 27.79 & 4.77 & 0 & 33 & -2.51 & 10.46 & $.18^{* *}$ \\
$\quad \begin{array}{l}\text { Skills } \\
\quad \text { School }\end{array}$ & 115 & 20.51 & 4.84 & 0 & 27 & -1.21 & 2.34 & .13 \\
$\begin{array}{c}\text { Functioning } \\
\text { Affective } \\
\quad \text { Strength }\end{array}$ & 115 & 15.16 & 4.06 & 0 & 21 & -1.16 & 2.44 & .12 \\
$\quad \begin{array}{c}\text { Strength } \\
\text { Index }\end{array}$ & 115 & 123.33 & 22.00 & 6 & 155 & -2.28 & 8.72 & $.13^{*}$ \\
\hline
\end{tabular}

${ }^{*} \mathrm{p}<.05 ; * * \mathrm{p}<.01$; standard skewness error for all variables is 0.23 ; standard kurtosis error for all variables is 0.45

Overall Strength Index results and subscale results

Table 3 shows the descriptive parameters of the scaled results obtained in the research.

Table 3. Descriptive parameters of variable scaled results

\begin{tabular}{cllllllll}
\hline & $\mathrm{N}$ & $\mathrm{M}$ & $\mathrm{SD}$ & $\mathrm{Min}$ & $\mathrm{Max}$ & skewness & kurtosis & $\mathrm{K}-\mathrm{S}$ \\
\hline $\begin{array}{c}\text { Interpersonal } \\
\quad 115\end{array}$ & 11.03 & 3.34 & 1 & 18 & -0.47 & 0.67 & .10 \\
$\begin{array}{c}\text { Strength } \\
\text { Family }\end{array}$ & 115 & 12.17 & 2.94 & 3 & 17 & -0.68 & 0.40 & .11 \\
$\begin{array}{c}\text { Involvement } \\
\text { Intrapersonal }\end{array}$ & 115 & 10.17 & 2.86 & 1 & 15 & -0.50 & 0.27 & .10 \\
$\begin{array}{c}\text { Strength } \\
\quad \text { School }\end{array}$ & 115 & 10.29 & 3.06 & 1 & 16 & -0.21 & -0.42 & .12 \\
$\begin{array}{c}\text { Functioning } \\
\text { Affective } \\
\text { strength }\end{array}$ & 115 & 10.24 & 3.23 & 1 & 16 & -0.39 & 0.18 & .09 \\
\hline
\end{tabular}

$* p<.05 ; * * p<.01$; standard skewness error for all variables is 0.23 ; standard kurtosis error for all variables is 0.45

It was apparent (Table 3) that the scaled results were normally distributed, which was not surprising since the scaled results were made according to a predetermined normal distribution with the arithmetic mean 
$\mathrm{M}=10$ and the standard deviation of $\mathrm{SD}=3$. By transferring the results of the participants to the predetermined scaled results, a difference was found in boys' and girls' scales. The scaled results for girls had a smaller range than the boys result, and because of this discrepancy in the predetermined possible scale results, it was not possible to perform statistical data processing with these results, but it was only possible to objectively comment on the obtained values. Since a diagnostic questionnaire was used in this study, the obtained gross results could be expressed as so-called scaled results. It was interesting to note that no minimum value for any of the sub-scales was reached. Also, the mean values of all sub-scales indicated the average behavioural and emotional strengths. The mean value of 11.33 for Interpersonal Strength subscale fell within the range of $8-12$, which indicated the average behavioural and emotional strengths. This result was somewhat lower than in the study conducted by De Villiers and Van den Berg (2012), where the results pointed to strong Interpersonal strengths, but on a smaller sample $(\mathrm{N}=$ 88). Compared to a larger sample survey (Uhing, Mooney, \& Ryser, 2005), these results were somewhat higher, but were still within the range of the average Interpersonal Strengths.

The average value of Family Involvement subscale results was the highest one out of all subscales $(M=12.17)$, but it was still within the range of results that indicated the average strengths in this area of functioning. Concerning the obtained values, and compared to the two abovementioned studies, it reoccupied the place in the middle. The result was somewhat lower than that of a smaller sample (De Villiers \& Van den Berg, 2012), and higher than that of a larger sample (Uhing, Mooney, \& Ryser, 2005). 
A similar trend could be seen in the Affective Strength subscale. Namely, with this mean value, the results of the survey respondents could again be placed in the middle. On the other hand, the mean values of the Intrapersonal Strength and School Functioning subscales were somewhat lower than the results in the aforementioned studies, but still, together with the results on the other subscales, they indicated the average behavioural and emotional strengths of the entire group (Table 2).

After summarizing the scaled results of the subscales, it was possible to compute the values obtained into the Strength Index, which represented the most reliable overall assessment of the child's behavioural and emotional strengths (Epstein, 2004). Descriptive parameters of the Strength Index value $(\mathrm{M}=105.10 ; \mathrm{SD}=17.45 ;$ skewness $=-0.7 ;$ kurtosis=1.35; K-S=.06) showed that the results were normally distributed. The mean value of the Strength Index was 105.10, and it was placed as such in the range of 90-110, which was characterized as the average behavioural and emotional strengths. Compared to a larger sample study (Uhing, Mooney, \& Ryser, 2005), the result was higher, but it still belonged to the category of the average behavioural and emotional strengths. The above confirmed the first research hypothesis (H1). Namely, most respondents achieved the average scores on the Scale (according to the mean value of the subscales), pointing out that the average scores were achieved also on individual subscales, as well as on the overall assessment of the child's behavioural and emotional strengths, that is, the Strength Index.

It is evident from Figure 1 that a large number of respondents (43.48\%) have shown the average behavioural and emotional strengths. They were rated as satisfactory and on average common in everyday functioning. 
The sample also had a significant number of subjects who achieved results in ranges of 111-120,121-130 and > 130, which represented the above-average, strong, and very strong behavioural and emotional strengths.

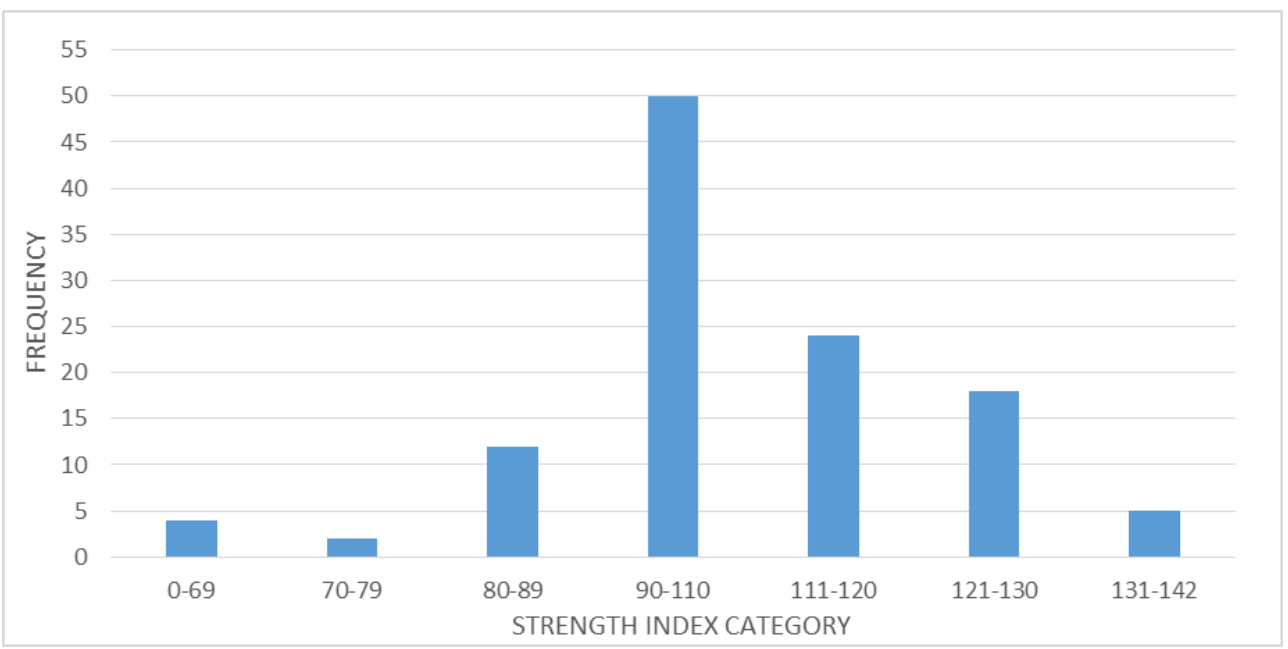

Figure 1 Display of frequency of individual Strength Index categories

Their share in the sample was $40.87 \%$, and the probability of the behavioural and emotional disorders was extremely low. The values of the Strength Index ranging from 80 to 89 were from those participants whose strengths were rated as below-average. In this sample, their percentage was $10.43 \%$. Furthermore, among the participants in this research, there was also a smaller number of very low results, namely $5.22 \%$. The individuals, whose results pointed to below-average and poor behavioural and emotional strengths, probably had very little personal strengths, and might have a poor opinion or awareness of themselves, that they were immature, or that they might have a negative perception and feelings about peers and adults. Since this instrument was a diagnostic questionnaire, such low results indicated that these children were at high risk of being identified with some form of behavioural and emotional disorders (Epstein, 2004). 
The relationship between school success and the development of social and emotional skills

To examine the correlation of school achievements in the first to the fourth grade, the fifth and the sixth grades with individual behavioural and emotional competencies, Spearman correlations were calculated.

Table 4. Spearman correlation coefficient results-correlation of grade point average in the first to the fourth grade, the fifth and the sixth grade with individual social and emotional skills

\begin{tabular}{llllll}
\hline & IS & FI & IaS & SF & AS \\
\hline GPA1 & .03 & -.01 & -.00 & .14 & -.03 \\
GPA2 & .10 & .01 & -.10 & $.34^{*}$ & -.11 \\
GPA3 & .18 & -.07 & -.07 & $.34^{*}$ & -.07 \\
\hline
\end{tabular}

$*_{p}<.05$

Table 4 illustrates the statistically significant moderate positive correlation between School Functioning and school success in the fifth and the sixth grades of elementary school, with a level of risk of misstatement less than 5\%. Individuals who achieved a higher score on the School Functioning subscale also had a higher grade point average at the end of the school year in the fifth and the sixth grade of elementary school. Finding that a child participated in classes, assessed its competences in the classroom and at school in general as good, and that this was related to his/her school success was found in other researches as well. For instance, Valiente, Lemery-Chalfant, Swanson, \& Reiser (2008) found a positive correlation between self-regulation in school assignments, participation in school, and academic achievement. In the study conducted by Gumore and Arsenia (2002), it was also found that students who had positive opinions (attitudes) 
about their academic competences had better success at school. Along with positive attitudes about their own academic competences, responsible behaviour, as a critical aspect of social competence in the classroom context, was a powerful predictor of academic performance in early adolescence as well (Wentzel, 1991).

No significant correlation between the other individual social and emotional competences and school achievement in any class has been found in this research. These results are contradictory to those in other researches. Other studies emphasize the importance of family characteristics as school success predictors. Thus, Gingsburg and Bronstein (1993) found that family styles that promoted autonomy were linked to intrinsic motivation in school, and ultimately to better school success. The parent-child relationship and parenting styles were some of the aspects that affected the development of cognitive skills which served as the foundation of school achievement (Wentzel, 1994). Authoritative parenting style was positively associated with memory development, cognitive distancing, contextualization skills, and selfregulated problem-solving. Generally speaking, children of authoritative parents had higher grades and more positive attitudes toward school than children of parents with permissive or authoritarian parenting styles (Wentzel, 1994).

Although there was no correlation found between the Affective Strength, Intrapersonal Strength, and Interpersonal Strength subscales, and the school achievement in this research, it was variously proven in other researches. According to Eisenberg, Sadovsky, and Spinrad (2005), the child's emotional regulation was also closely related to school success through some of its aspects which directly contributed to the child's readiness 
for school and academic competencies. Emotional regulation affected students' academic skills and motivation directly and indirectly through social skills, such as being accepted by others, and relationships with peers and teachers (Eisenberg, Sadovsky, \& Spinrad, 2005). Understanding emotions was also associated with behavioural problems, in a way that children (elementary school age) who had more pronounced behavioural problems showed deficits in understanding emotions. Furthermore, it was also found that intellectual functioning was negatively correlated to the degree of understanding of emotions (Cook, Greenberg, \& Kusche, 1994). Although the relationship between the ability to regulate behaviour and emotions in social situations and the school achievement was not found in our research, it was found in the study conducted by Edossa, Schroeders, Weinert and Artelt (2018). Specifically, it was determined that emotional and behavioural selfregulation were two separate constructs, and that self-regulation during the first few grades of elementary school had a positive impact on teachers' assessment of academic competencies in higher grades of elementary school.

The aforementioned suggested that the third hypothesis (H3), where it was assumed that there would be a positive correlation between the development of social and emotional skills and the school achievement, was not confirmed, in the way that the children with more developed social and emotional skills attained better success at school. A positive correlation was established only between the School Functioning and the school achievement in the fifth and the sixth grades.

Furthermore, no significant correlation was found between the overall social and emotional competence (Strength Index) and school success in any 
class, meaning that the hypothesis number two $(\mathrm{H} 2)$ of this study was not confirmed.

Table 5. Spearman Correlation Coefficient Results - The correlation between Grade point average (1st-4th, 5th and 6th grade) and the Strength Index

\begin{tabular}{cccc}
\hline & GPA1 & GPA2 & GPA3 \\
\hline SI & .06 & .05 & .09 \\
\hline
\end{tabular}

This result differed from those in other researches (Buljubašić Kuzmanović \& Botić, 2012; Oberle, Schonert-Reichl, Hertzman, \& Zumbo, 2014; Elias et al., 1997; Dougherty \& Sharkey, 2017), which found a positive correlation between social and emotional competences and the school success. Buljubašić, Kuzmanović and Botić (2012) confirmed that students had the most negative assessments of their own social skills, and the most positive assessments were found in excellent students, while very good students mostly "kept up" with excellent students, deviating slightly from their answers. In the context of our entire research and possible implications on pedagogical practice, research by Dougherty and Sharkey (2017) was posited as significant. They found a positive correlation between social and emotional strengths and the school success before and after implementing social and emotional learning programmes. Concerning the control group, students who participated in the programme had a better school achievement after completion of the programme. The success of implementing social and emotional learning programmes and their impact on school success, as well as the relationship of social and emotional competencies and school successes in the initial examinations, were studied in other research, where the results were equally positive (Payton et al., 2008; Cefai, Bartolo, Cavioni, \& Downes, 2018; Taylor et al., 2017; Oberle \& Schonert-Reichl, 2017; 
Haymovitz, Houseal-Allport, Lee \& Svistov, 2017; Durlak, Weissberg, Dymnicki, Taylor, \& Schellinger, 2011).

On the other hand, the results in this study deviated from the above listed results, and the reasons, which were also limitations of this research, could be found in several factors. One of them could be the inflation of very good and excellent grades, which was a growing trend in the education system in general. Table 7 shows that in all grades the number of very good and excellent grades is disproportionate to the number of good and sufficient grades. Although the number of excellent grades decreases with the transition of students to higher grades, the number of good and sufficient grades is only slightly increasing.

Table 6. Display of the frequency of general point averages by grades (first to fourth, fifth and sixth grade)

\begin{tabular}{cccc}
\hline & GPA1 & GPA2 & GPA3 \\
\hline 2 & 1 & 1 & 2 \\
3 & 5 & 8 & 6 \\
4 & 20 & 46 & 49 \\
5 & 89 & 60 & 58 \\
\hline
\end{tabular}

As it is well known, in the Croatian education system, school grades represent a certain type of ordinal scale. The degree of acquisition of knowledge, skills, and abilities are expressed in a numerical scale from one to five. However, it is important to emphasize that equal assessment does not encompass equal knowledge, since grades are subjected to different conditions in which they arise, but also to the subjective characteristics of the evaluator (Kadum-Bošnjak \& Brajković, 2007). Matijević and Radovanović (2011) emphasize the need to address the limited possibilities and justifications of statistical operations with numbers and categories divided in 
such a way. Since different scales, like these, allow for different statistical calculations, it is necessary to find the logic and purpose of these calculations. The most questionable statistics of estimates of certain variables for certain students is seen in computing grade point average (ordinal scale) in different subjects or in the average grades obtained on the basis of estimates of different variables (Matijević \& Radovanović, 2011). Calculating grade point average from different subjects (keeping in mind the fact that classification criteria in different subjects are extremely different) is quite questionable. Furthermore, grade point average in the form of a numerical grade from one to five was used in the survey, and it would be interesting to know in some future studies whether the results would have changed (and if so, how and in what way), were the collected general point average values expressed in decimal numbers. Bearing in mind the aforementioned, the assessment of students' academic competences could have been collected in different ways, ranging from scales that measured performance in specific areas (maths, reading, logical thinking), grades from particular school subjects and / or teacher assessments; all of which would possibly impact the final results of the research.

\section{CONCLUSION}

Given the emphasized limitations, the results of the study, point out to average and above-average social and emotional strengths of the majority of participants, which is posited as optimistic and positive. Results concerning the relationship between social and emotional competencies and the school achievement are not in accord with the premise that these competencies are an important predictor of the school achievement. Namely, a positive correlation has been found with only one social and emotional competence, 
School Functioning. These results then hardly correspond to the studies dealing with the same topic. For that very reason, potential reasons how these results emerged have been argued in the paper. Nonetheless, bearing in mind all the aforementioned, it is impossible to ignore the growing trend and the importance of this topic not in the school achievement context only, but, more importantly, in the holistic development of an individual where a school has a role of importance and responsibility. Therefore, it is necessary to inform and encourage educational policies creators, and direct them towards the implementation of social and emotional learning into curriculums on all educational levels. A special attention should be given to university level education, which educates kindergarten teachers, school teachers, pedagogues, and social pedagogues. Current pedagogical practice requirements, which increase is expected in the future, need professional educators in their institutions, who will design, implement, coordinate, and supervise social and emotional programs and activities. At the same time, one of their core responsibilities will be structured and systematic organization of teacher professional development and parent education, with a common goal of acquiring social and emotional competencies along with informing and involving the local community (Haymovitz, Houseal-Allport, Lee \& Svistova, 2017; Cefai et al., 2018). A well-envisioned, holistic, and integrated approach to the education of future generations is based on the development of social and emotional competencies which, then again, represent a foundation for the enhancement of pedagogical theory and practice. The sole purpose of this is to empower children, pupils, and students, so they can fully develop their potentials and answer the demands of these turbulent social times and circumstances appropriately. 


\section{REFERENCES}

Buckley, J. A., \& Epstein, M. H. (2004). The Behavioral and Emotional Rating Scale-2 (BERS-2): Providing a comprehensive approach to strength-based assessment. The California School Psychologist, 9(1), 21-27.

Buljubašić Kuzmanović, V., \& Botić, T. (2012). Odnos školskog uspjeha i socijalnih vještina kod učenika osnovne škole [Relationship between social skills and academic achievement in elementary school students]. Život $i$ škola: časopis za teoriju $i$ praksu odgoja $i$ obrazovanja, 58(27), 38-53.

Cefai, C., Bartolo, P. A., Cavioni, V., \& Downes, P. (2018). Strengthening social and emotional education as a core curricular area across the EU: A review of the international evidence. Analytical Report. Luxemburg: Publications Office of the European Union.

Collaborative for Academic, Social, and Emotional Learning (2003). Safe and Sound: An educational leader's guide to evidence based social and emotional (SEL) programs. Chicago.

Collaborative for academic, social, and emotional learning (2013). Effective social and emotional learning programs. Preschool and Elementary School Edition.

Cook, E. T., Greenberg, M. T., \& Kusche, C. A. (1994). The relations between emotional understanding, intellectual functioning, and disruptive behavior problems in elementary-school-aged children. Journal of abnormal child psychology, 22(2), 205-219.

Dougherty, D., \& Sharkey, J. (2017). Reconnecting youth: promoting emotional competence and social support to improve academic achievement. Children and Youth Services Review, 74, 28-34.

Durlak, J. A., Weissberg, R. P., Dymnicki, A. B., Taylor, R. D., \& Schellinger, K. B. (2011). The impact of enhancing students' social and emotional learning: A meta-analysis of school-based universal interventions. Child development, 82(1), 405-432.

Edossa, A. K., Schroeders, U., Weinert, S., \& Artelt, C. (2018). The development of emotional and behavioral self-regulation and their 
effects on academic achievement in childhood. International Journal of Behavioral Development, 42(2), 192-202.

Eisenberg, N., Sadovsky, A., \& Spinrad, T. L. (2005). Associations of emotion-related regulation with language skills, emotion knowledge, and academic outcomes. New Directions for Child and Adolescent Development, 2005(109), 109-118.

Elias, M. J., Parker, S., Kash, V. M., Weissberg, R. P., \& O’Brien, M. U. (2008). Social and emotional learning, moral education, and character education: A comparative analysis and a view toward convergence. Handbook of Moral and Character Education, 248-266.

Elias, M. J., Zins, J. E., Weissberg, R. P., Frey, K.S., Greenberg, M. T., Haynes, N. M., Kessler, R., Schwald-Stone, M. E., \& Shriver, T. P. (1997). Promoting social and emotional learning: Guidelines for educators. USA: Alexandria, Virginia: Association for Supervision and Curriculum Development.

Epstein, M. H. (2004). Behavioural and Emotional rating scale-a strengthbased approach to assessment (Second edition): Examiner's manual. Austin, Texas: PRO-ED, Inc.

Epstein, M. H., Mooney, P., Ryser, G., \& Pierce, C. D. (2004). Validity and reliability of the behavioral and emotional rating scale: Youth rating scale. Research on Social Work Practice, 14(5), 358-367.

Gardner, H. (1993). Frames of mind: The theory of multiple Intelligences. New York: Basic Books.

Ginsburg, G. S., \& Bronstein, P. (1993). Family factors related to children's intrinsic/extrinsic motivational orientation and academic performance. Child Development, 64(5), 1461-1474.

Gresham, F. M., \& Elliott, S. N. (2017). Social skills improvement system social-emotional learning. Bloomington, MN: NCS Pearson.

Gumora, G., \& Arsenio, W. F. (2002). Emotionality, emotion regulation, and school performance in middle school children. Journal of school psychology, 40(5), 395-413.

Hao, J. (2015). Piloting the Behavioral and Emotional Rating Scale-2 (BERS-2) in a Chinese primary school. International Master Degree 
Program in education. Jyvaskyla: Faculty of Education. University of Jyvaskyla.

Haymovitz, E., Houseal-Allport, P., Lee, R. S., \& Svistova, J. (2017). Exploring the perceived benefits and limitations of a school-based social-emotional learning program: A concept map evaluation. Children \& Schools, 40(1), 45-54.

Kadum-Bošnjak, S., \& Brajković, D. (2007). Praćenje, provjeravanje i ocjenjivanje učenika u nastavi. [Monitoring, testing and evaluating pupils in classes] Metodički obzori: časopis za odgojno-obrazovnu teoriju i praksu, 2(4), 35-51.

Lambert, M. C., Sointu, E. T., \& Epstein, M. H. (2019). A comprehensive review of international research using the Behavioral and Emotional Rating Scale. International Journal of School \& Educational Psychology,7(3), 215-226.

Matijević, M., \& Radovanović, D. (2011). Nastava usmjerena na učenika. Zagreb: Školske novine. Zagreb.

Merkaš, M. (2012). Uloga obitelji u razvoju socijalne kompetencije adolescenata [The role of the family in development of adolescent social competence] (Doctoral dissertation). Zagreb: University of Zagreb.

Miljković, D., Đuranović M. \& Vidić, T. (2019). Odgoj i obrazovanje-iz teorije $u$ praksu [Education - from theory to practice]. Zagreb: Učiteljski fakultet u Zagrebu, IEP-D2.

Munjas Samarin, R., \& Takšić, V. (2009). Programi za poticanje emocionalne i socijalne kompetentnosti kod djece i adolescenata. Suvremena psihologija, 12(2), 355-370.

Oberle, E., \& Schonert-Reichl, K. A. (2017). Social and emotional learning: recent research and practical strategies for promoting children's social and emotional competence in schools. In: Handbook of Social Behavior and Skills in Children (pp. 175-197). Cham: Springer.

Oberle, E., Schonert-Reichl, K. A., Hertzman, C., \& Zumbo, B. D. (2014). Social-emotional competencies make the grade: Predicting academic success in early adolescence. Journal of Applied Developmental Psychology, 35(3), 138-147. 
Payton, J., Weissberg, R. P., Durlak, J. A., Dymnicki, A. B., Taylor, R. D., Schellinger, K. B., \& Pachan, M. (2008). The positive impact of social and emotional learning for kindergarten to eighth-grade students: Findings from three scientific reviews. technical report. Collaborative for Academic, Social, and Emotional Learning (NJ1).

Schonert-Reichl, K. A., Kitil, M. J., \& Hanson-Peterson, J. (2017). To reach the students, teach the teachers: A National scan of teacher preparation and social \& emotional learning. A Report prepared for CASEL. Collaborative for academic, social, and emotional learning.

Sointu, E. T., Savolainen, H., Lambert, M. C., Lappalainen, K., \& Epstein, M. H. (2014). Behavioral and emotional strength-based assessment of Finnish elementary students: Psychometrics of the BERS-2. European Journal of Psychology of Education, 29(1), 1-19.

Taylor, R. D., Oberle, E., Durlak, J. A., \& Weissberg, R. P. (2017). Promoting positive youth development through school-based social and emotional learning interventions: A meta-analysis of follow-up effects. Child Development, 88(4), 1156-1171.

Uhing, B. M., Mooney, P., \& Ryser, G. R. (2005). Differences in strength assessment scores for youth with and without ED across the Youth And Parent Rating Scales of the BERS-2. Journal of Emotional and Behavioral Disorders, 13(3), 181-187.

Valiente, C., Lemery-Chalfant, K., Swanson, J., \& Reiser, M. (2008). Prediction of children's academic competence from their effortful control, relationships, and classroom participation. Journal of Educational Psychology, 100(1), 67.

Wentzel, K. R. (1991). Relations between social competence and academic achievement in early adolescence. Child Development, 62(5), 10661078.

Wentzel, K. R. (1994). Family functioning and academic achievement in middle school: A social-emotional perspective. The Journal of Early Adolescence, 14(2), 268-291. 